\title{
MEDIA SOSIAL DALAM HUBUNGAN INTERNASIONAL
}

\author{
Agus Subagyo
}

\begin{abstract}
This article analyzes the development of social media, such as Facebook, Twitter, Instagram, YouTube, and Watsapps, in international relations, especially the practice of diplomacy, which gave birth to digital diplomacy. Social media has changed the world landscape of diplomacy from manual/traditional diplomacy leading to modern/digital diplomacy, so that the practice of diplomacy is carried out in an open, transparent, fast, effective and efficient manner. The development of information, internet and computer technology has been utilized in the implementation of diplomatic duties in diplomacy in international forums.
\end{abstract}

Keywords: Information Technology, Social Media, Digital Diplomacy.

\section{Pendahuluan}

Lanskap hubungan internasional saat ini telah mengalami perubahan siginifikan, khususnya dengan perkembangan teknologi informasi dan komunikasi, terutama di era revolusi industri 4.0. Akselerasi globalisasi, pasar bebas dan perdagangan bebas telah mendorong dunia tanpa batas, batas antar negara menjadi tiada, dan setiap orang dari berbagai negara bebas melakukan interaksi secara langsung, real time, dan online. Aktor negara tidak lagi 
menjadi pemain utama dalam percaturan politik internasional, karena menguatnya aktor non negara, seperti individu, NGO, pers/ media, dan organisasi regional yang justru mampu mempengaruhi opini publik dunia dan mampu membangun citra dunia secara massif, terstruktur dan sistematis.

Apabila di masa lalu, semua kejadian, peristiwa, dan fenomena global diinformasikan melalui media mainstream, khususnya media massa (baik media cetak maupun media elektronik), yang umumnya berjalan lama, lambat dan penuh pencitraan, maka sekarang ini, dunia memasuki babak baru, dimana semua rangkaian peristiwa dunia disajikan kepada publik secara real time, live, cepat, dan apa adanya. Bahkan, setiap orang mampu menjadi aktor hubungan internasional dengan meliput, merekam, maupun menyajikan berita menjadi informasi yang layak disajikan kepada masyarakat dunia, dalam bentuk jurnalisme warga (citizen journalism) misalnya.

Hal ini bisa terjadi karena "media sosial"/social media/ medsos/sosmed. Kekuatan media sosial menjadi sarana bagi setiap aktor untuk dijadikan sebagai sarana informasi, mobilisasi, sosialisasi, dan promosi terhadap berbagai produk kebijakan global maupun propaganda yang ampuh untuk membangun jejaring maupun mempengaruhi masyarakat global (Onong Uchjana Effendy, 2003:83). Media sosial telah memberi kekuatan kepada aktor-aktor non negara untuk tampil di garda terdepan dalam interaksi antar negara sehingga sangat efektif mempengaruhi keputusan global maupun kebijakan global antar negara dalam setiap forum internasional. Media sosial, 
seperti Facebook, Instagram, Twitter, dan Youtube, merupakan fenomena baru dalam hubungan internasional sehingga mendorong terjadinya "digitalisasi" hubungan internasional, yang mengarah pada postur baru "hubungan internasional 4.0."

Di masa lalu, setiap kejadian internasional hanya diliput dan diberitakan oleh media mainstream baik media cetak maupun media elektronik kepada masyarakat dunia dalam waktu yang lama, dan dimasa sekarang, setiap kejadian dapat diakses oleh publik melalui gadget/smartphone secara real time, sehingga bisa cepat menjadi viral, di mana seluruh dunia dapat mengetahuinya dalam waktu yang singkat, cepat, dan sekejap. Keberadaan internet, website, dan blog di era revolusi industri 4.0. adalah kebutuhan yang harus dilakukan oleh semua aktor dalam hubungan internasional. Aktor negara, yang terepresentasi di jajaran kementerian luar negeri, kedutaan, konsulat dan perwakilan diplomatik lainnya harus tanggap dan responsif sehingga tidak kalah dengan aktor non negara yang sangat aktif di dunia maya (cyber space), menjelma menjadi warga dunia maya (netizen, internet citizen). Aktor individu dalam hubungan internasional ternyata tampil eksis menjadi netizen yang diperhitungkan dalam kebijakan publik global, dengan cara membangun komunitas dunia maya, membuat gerakan, memobilisasi dukungan atas isu tertentu, membangun opini publik global, dan pada akhirnya mampu mengarahkan agenda setting global. 


\section{Perkembangan Media Sosial}

Dalam perspektif komunikasi internasional, media massa/pers terbagi dalam media cetak, media elektronik, media online, dan media sosial (Nurudin, 2017: 8). Media sosial telah mampu mengimbangi media mainstream atau media tradisional, seperti media cetak dan media elektronik. Pengaruh media sosial tidak diragukan lagi mampu menjadi media alternatif yang dapat diakses dengan mudah oleh semua komunitas global. Media cetak dan media elektronik dinilai bersifat lambat, kurang cepat dan formalistik mulai kurang dilirik oleh netizen (Feldman, 2005: 32). Netizen mulai melirik media sosial sebagai sumber informasi maupun sumber menyebarkan berita yang langsung mengena di hati masyarakat global.

Berdasarkan data tahun 2018, lima negara dengan jumlah pengguna Facebook terbesar di dunia adalah India 270 juta, Amerika Serikat (AS) 240 juta, Indonesia 140 juta, Brazil 130 juta, dan Mexico 85 juta. Indonesia menempati posisi ketiga sebagai negara pengguna Facebook terbesar di dunia.

Sementara itu, jumlah pengguna Instagram di dunia dapat dilihat datanya sebagai berikut: AS 120 juta, Brazil 61 juta, India 59 juta, Indonesia 56 juta, dan Turki 34 juta. Dari sisi pengguna Instagram, Indonesia menempati urutan keempat terbesar di dunia, yang tentunya akan berpotensi meningkatkan posisi tawar Indonesia di dunia internasional. 
Sedangkan untuk media sosial berupa Twitter, Indonesia berada pada urutan ke-12 sebagai pengguna Twitter terbesar di dunia, dengan total jumlah pengguna mencapai 6,6 juta. Jepang dan Arab Saudi sebagai negara Asia yang masuk lima besar pengguna Twitter terbanyak di dunia. Hal ini menjadi bekal agar supaya menjadikan Indonesia lebih berkiprah lagi dalam dunia internasional melalui media sosial.

Sementara itu, data yang diterbitkan oleh Wearesosial Hootsuite, pada bulan Januari 2019, pengguna media sosial aktif di seluruh Indonesia telah mencapai 150 juta penduduk atau dalam persentase mencapai $56 \%$ dari total populasi. Sedangkan pengguna media sosial mobile/gadget/smartphone berkisar 130juta penduduk. Data ini menggambarkan bahwa Indonesia sangat aktif dalam dunia maya dan aktif dalam menggunakan media sosial di dunia maya.

Perkembangan media sosial ini telah bermanfaat dalam hubungan internasional, khususnya dunia diplomasi, terutama di Indonesia. Dunia diplomasi Indonesia responsif mengadaptasi perubahan global di dunia maya, sehingga Kemenlu RI melakukan berbagai penyesuaian, khususnya membentuk unit kerja/satuan kerja/direktorat yang menangani diplomasi digital. Selain itu, Kemenlu RI juga mendorong para diplomat untuk "melek" terhadap media sosial, memiliki akun pribadi media sosial, dan mendorong terbentuknya akun resmi media sosial di setiap direktorat yang ada di dalam organisasi Kemenlu RI. 


\section{Lahirnya Diplomasi Digital}

Dalam perspektif tradisional, dunia diplomasi dibayangkan sebagai kegiatan yang tertutup, rahasia, kaku, dan formal, sehingga jauh dari kata transparan, terbuka, santai, dan informal. Diplomasi dipersepsikan sebagai aktifitas para diplomat di meja perundingan, di ruang tertutup, penuh seremonial, dan memakai baju rapi dengan jas berdasi. Masyarakat hanya mampu melihat dan mendengar semua rangkaian diplomasi melalui media tradisional seperti media cetak dan elektronik, seperti surat kabar dan televisi, yang sifatnya tidak real time atau live.

Namun, dengan hadirnya media sosial, dunia masuk pada dunia digital, praktek diplomasi lebih terbuka, transparan, sehingga semua proses dan hasil diplomasi dapat diakses oleh masyarakat dunia secara cepat, tepat, dan benar (Corneliu \& Marcus, 2015: 71). Diplomasi bukan dianggap sebagai sesuatu yang sakral dan kaku, melainkan lebih luwes, santai, dan fleksibel, jauh dari kesan penuh aturan, regulasi dan prosedur tetap yang ketat. Bahkan, setiap orang atau individu mampu menjadi diplomat bagi setiap negaranya masing- masing melalui media sosial.

Melalui media sosial, setiap orang dari berbagai negara dapat melihat dan berkunjung ke negara lain karena tertarik oleh blog atau website yang dibuat oleh individu di negara lain. Informasi tentang negara lain bisa didapatkan dari berbagai media sosial yang dimiliki oleh warga negara di negara lain 
(Olubukola S. 2016: 25). Bahkan, terjadi interaksi antara warga negara di suatu negara dengan warga negara di negara lain, membentuk komunitas dunia maya, saling membangun jejaring, yang bermuara pada saling kunjung antar negara, yang tentunya ini menjadikan pola interaksi hubungan internasional menjadi lebih kompleks.

Fenomena inilah yang kemudian dalam perspektif hubungan internasional dengan berbagai istilah, seperti Network Diplomacy, Online Diplomacy, Wireless Diplomacy, Electronic Diplomacy, Cyber Diplomacy, Daring Diplomacy, dan Real Time Diplomacy. Intinya, lahirlah diplomasi digital sebagai diplomasi modern, yang menggeser diplomasi tradisional, diplomasi manual, dan diplomasi kuno. Artinya, dunia diplomasi telah memanfaatkan peralatan teknologi informasi dan komunikasi, khususnya media sosial, dalam melakukan berbagai aktifitas dan rangkaian praktik diplomasi.

Dari sisi aktor hubungan internasional, perkembangan media sosial telah menguatkan aktor non negara/non state actor. Aktor non negara atau non state actor menjadi lebih dominan, seperti individu, NGO, dan civil society, mempengaruhi setiap rangkaian perundingan dan praktikpraktik diplomasi di dunia. Diplomat sebagai respresentasi "state actor" mendapatkan tantangan aktor baru, yang kemudian melahirkan diplomasi publik. Aktor Individu mendapatkan saluran dan kanalisasi berkat adanya media sosial untuk menyuarakan aspirasi, pendapat, opini, maupun agendanya untuk disuarakan ke ranah global melalui jejaring 
antar netizen di dunia maya, yang mampu melahirkan opini publik global.

Dari sisi alat, media sosial dijadikan sebagai alat, sarana, dan wahana untuk melakukan praktik diplomasi (Andreas, 2013: 49). Media sosial dijadikan sebagai alat diplomasi setiap negara. Akun website, Facebook, Twitter, Instagram, Youtube, dan blog resmi mulai dibuat dan dipergunakan oleh kemenlu, kedutaan, konsulat, dan perwakilan di luar negeri. Bahkan, pemanfaatan blog, Facebook, Instagram, Twitter, dan Youtube pribadi para diplomat maupun semua pegawai kemenlu, kedutaan, konsulat dan perwakilan resmi lainnya terus digencarkan. Artinya, media sosial diberdayakan seoptimal mungkin untuk mendukung tujuan diplomasi untuk mencapai kepentingan nasional setiap negara.

Dari sisi metode, media sosial dijadikan sebagai metode mobilisasi dukungan, sarana membangun opini publik, dan menjaring aspirasi masyarakat, melalui tagar/tagar sebagai data, maupun "trending topic" di twitter. Aplikasi Youtube juga sering dipergunakan sehingga sampai ada video yang viral, termasuk upaya tracking data melalui media sosial untuk kepentingan bahan diplomasi maupun jajak pendapat untuk mengetahui pendapat publik dunia tentang suatu isu tertentu. Bahkan, kalau dilihat secara historis, peran media sosial, khususnya Facebook dan Twitter, pada perkembangan "Arab Spring" sangat besar sekali, karena berkat Facebook dan Twitter, maka pergerakan rakyat dan mahasiswa serta 
komponen civil society di Tunisia, Mesir, Libia, dan beberapa negara Arab lainnya, berhasil menggulingkan rezim otoriter yang berkuasa saat itu (M. Agastya ABM, 2013: 13).

\section{Dampak Positif Media Sosial}

Dilihat dari perspektif kekinian, media sosial memiliki dampak positif yang dapat dimanfaatkan oleh para diplomat sebagai sarana untuk menunjang tugas-tugas diplomatik, khususnya ketika para diplomat tersebut sedang bertugas di luar negeri atau pada saat ditempatkan di kantor perwakilan luar negeri. Sebagaimana diketahui bahwa dalam Konvensi Wina 1961, tugas diplomat adalah representing, promoting, protecting, negotiating, dan reporting. Ditambah lagi dengan disseminating yang melekat pada diri seorang diplomat.

Dalam melaksanakan tugas-tugas diplomatik tersebut, para diplomat sekarang ini memanfaatkan media sosial, baik akun media sosial yang dimiliki resmi oleh kantor kedutaan/konsulat maupun akun media sosial milik pribadi para diplomat, sehingga akan sangat efektif dan efisien untuk mencapai tujuan-tujuan diplomatik (LPPM Unpar, 2017: 77). Dampak positif media sosial bagi tugas diplomatik dapat diuraikan sebagai berikut:

- Representing. Seorang diplomat merupakan wakil resmi negara di negara tempat diplomat tersebut ditempatkan, sehingga segala ucapan, perkataan, sikap, perilaku dan perbuatannya mencerminkan negara asal diplomat tersebut. Pernyataan diplomat 
tersebut dianggap sebagai pernyataan resmi dari negara asal diplomat tersebut. Dengan kata lain, seorang diplomat merupakan juru bicara resmi negara di luar negeri. Dalam konteks ini, seorang diplomat harus aktif, responsif dan partisipatif terhadap berbagai isu, peristiwa dan kejadian di negara tempat diplomat ditugaskan. Oleh karena itu, seorang diplomat sekarang ini menggunakan media sosial sebagai sarana untuk menyatakan sikap atas setiap peristiwa yang terjadi. Semua kejadian direspon oleh diplomat dengan pernyataan yang dimuat di media sosial, sebagai pernyataan resmi negaranya, sehingga mudah dibaca, mudah diakses, dan mudah ditanggapi oleh publik. Setiap diplomat saat ini memberikan respon, membuat press release, maupun menyatakan sikap/pernyataan, yang disalurkan melalui media sosial, sehingga lebih efektif, efisien, cepat dan jelas.

- Promoting. Seorang diplomat memiliki tugas untuk mempromosikan, mensosialisasikan, mengiklankan, memperkenalkan dan memasarkan berbagai produk nasional maupun potensi yang ada di daerahdaerah. Seorang diplomat dituntut untuk menjadi "promotor" yang baik sehingga mampu membuat publik global atau masyarakat dinegara diplomat tersebut ditempatkan mengenal berbagai 
produk termasuk barang dan jasa serta berbagai potensi ekonomi, peluang bisnis, iklim investasi, dan pariwisata. Targetnya, masyarakat dunia mengenal,mengetahui, dan mengunjungi negara asal diplomat berasal. Saat ini, para diplomat Indonesia memanfaatkan media sosial resmi maupun akun media sosial pribadi untuk dijadikan sarana mempromosikan berbagai produk barang dan jasa serta potensi wisata/kekayaan alam Indonesia ke luar negeri agar supaya masyarakat dunia mengetahui tentang Indonesia, mengunjungi Indonesia sebagai turis maupun sebagai investor, serta melakukan kerjasama berbagai bidang dengan Indonesia. Media sosial dinilai sangat efektif untuk promosi dan pemasaran Indonesia di luar negeri, karena tidak sedikit orang luar mengetahui tentang Indonesia dari media sosial, baik Facebook, Instagram, blog, maupun sarana media sosial lainnya.

- Protecting. Seorang diplomat memiliki tugas untuk melindungi warga negaranya di luar negeri apabila warga negara tersebut mendapatkan masalah, ancaman maupun kesulitan di luar negeri. Diplomat wajib melakukan pertolongan, bantuan dan advokasi/pendampingan terhadap warga negara yang mengalami persoalan hukum, menjadi korban kriminalitas maupun persoalan lainnya di 
luar negeri. Upaya melindungi warga negaranya di luar negeri merupakan keharusan bagi diplomat yang bertugas di luar negeri, baik di kedutaan maupun di konsulat. Dalam konteks ini, Kemenlu RI telah memanfaatkan media sosial sebagai sarana untuk melindungi warga negara Indonesia di luar negeri yang menjadi TKI dengan aplikasi "Safe Travel". Aplikasi Safe Travel menggunakan sistem geo tagging yang dapat mendeteksi posisi dan keberadaan eksisting warga negara Indonesia di luar negeri, yang dilengkapi dengan fitur panic button yang terhubung dengan smartphone, sehingga ketika WNI di luar negeri mendapatkan ancaman, intimidasi maupun potensi penyiksaan, kekerasan atau kriminalitas, maka tinggal menekan panic button, maka pihak petugas atau diplomat di kedutaan atau konsulat Indonesia akan mendatangi lokasi geo tagging tersebut untuk memberikan bantuan dan penyelamatan. Selain itu, pihak kedutaan dan konsulat juga dapat menyampaikan berbagai informasi kepada WNI di luar negeri melalui media sosial tentang berbagai kerawanan, indeks kerawanan dan peta kerawanan di negara-negara di dunia agar supaya WNI d luar negeri lebih waspada dan hati- hati.

- Negotiating. Seorang diplomat mempunyai tugas 
sebagai negosiator dalam setiap perundingan membahas berbagai persoalan dan permasalahan yang bersifat bilateral, trilateral maupun multilateral. Keahlian negosiasi bagi seorang diplomat sangat penting, khususnya public speaking dan public writing, sehingga mampu berbicara,kecakapan menyampaikan pendapat, meyakinkan pihak lain, maupun menyajikan gagasan dan ide melalui tulisan berupa press release dan lain-lain. Dalam melakukan tugas negosiasi tersebut, seorang diplomat umumnya saat ini menggunakan media sosial sebagai sarana untuk merekam situasi, kondisi, dan kejadian melalui media sosial untuk dijadikan sebagai bahan untuk melakukan negosiasi. Isu-isu yang menjadi tema dan pembahasan dalam sebuah perundingan antar negara biasanya mendorong para diplomat untuk mencari opini publik dari masyarakat melalui media sosial. Fitur trending topic di media sosial Twitter, tagar di Instagram, dan viral di Youtube umumnya dijadikan sebagai pertimbangan bagi para diplomat untuk menyusun strategi, mengatur taktik, dan menetapkan kesepakatan atas peristiwa yang dirundingkan antar diplomat. Para diplomat memanfaatkan media sosial sebagai upaya merekam kehendak publik dan menyaring pendapat, opini, ide dan 
gagasan publik tentang berbagai isu yang dirundingkan oleh para diplomat di meja perundingan.

- Reporting. Seorang diplomat diberi amanah untuk melaporkan kepada atasan tentang kesepakatan, kejadian, peristiwa yang terjadi di suatu negara. Pelaporan kepada kemenlu nya masing-masing maupun kepada pihak terkait lainnya umumnya dilakukan di masa lalu melalui sandi-sandi rahasia yang sulit dibaca dan diakses oleh publik. Kerahasiaan laporan seorang diplomat kepada atasannya sangat diutamakan sehingga sarana pelaporan menggunakan jaringan rahasia, kabelkabel rahasia, dan sistem komunikasi sandi yang diproteksi secara ketat dan rumit. Namun demikian, di era saat ini, proses pelaporan diplomat kepada atasan atas berbagai perundingan, peristiwa, kejadian dan isu tertentu dilakukan dengan mudah menggunakan media sosial. Jaringan Whatsapp, Line,Snapchat, Telegram dan lain-lain dipergunakan oleh para diplomat untuk memberikan laporan, update terkini, maupun breaking news kepada atasannya, maupun kepada pihak terkait lainnya, sehingga berjalan secara cepat, tepat, efektif, dan efisien. Di era media sosial seperti sekarang ini, seolah-olah 
sudah tidak ada lagi kerahasiaan, karena semua serba terbuka, mudah diakses publik, dan seakan-akan tidak ada yang bisa ditutup-tutupi lagi.

- Disseminating. Satu tambahan lagi, seorang diplomat di era kekinian, mengemban amanah untuk melakukan sosialisasi, penyebarluasan, maupun diseminasi terhadap berbagai aturan, regulasi, maupun kesepakatan perundingan internasional. Seorang diplomat harus menyampaikan ke publik tentang serangkaian capaian yang telah diraih kepada publik agar supaya publik mengetahui prestasi yang telah diraih oleh para diplomat Indonesia. Apabila di masa lalu, upaya penyebarluasan informasi maupun capaian yang telah diraih dilakukan dengan menggunakan media massa, baik media cetak dan elektronik, yang memakan waktu lama, formalistik, dan bertele-tele, maka saat ini upaya diseminasi capaian yang diraih oleh para diplomat dilakukan dengan menggunakan media sosial, yang lebih milenial, cepat, efektif, dan efisien, sehingga mudah dibaca, diakses dan dianalisis oleh masyarakat, khususnya generasi milenial. 


\section{Implikasi Media Sosial}

Dalam arus globalisasi saat ini, muncul perkembangan teknologi informasi, internet, komputer, dan berbagai peralatan modern dan canggih lainnya (Nasrullah, 2015: 18). Berbagai aplikasi teknologi dan software dibangun dan dirancang sehingga selain memberikan kemudahan pada aktifitas manusia, ternyata juga memberikan kesulitan dalam kehidupan manusia. Dunia saat ini memasuki era post truth (era pasca kebenaran), dimana kebenaran sangat tergantung pada keyakinan, emosi, opini, dan kepercayaan yang sifatnya subjektif. Bahkan, kamus Oxford telah menjadikan post truth sebagai "word of the year" tahun 2016, yang didasari oleh peristiwa keluarnya Inggris Raya dari Uni Eropa atau dikenal dengan istilah "Brexit" dan terpilihnya Donald Trump sebagai Presiden Amerika Serikat dalam Pilpres AS.

Era Post Truth semakian menggila dan mendunia di tengah kemajuan media sosial sehingga menjadikan dunia tanpa fakta, dunia dipenuhi opini, dunia yang bersifat subjektif, serta dunia tanpa objektifitas. Implikasi media sosial di era post truth bagi khazanah hubungan internasional adalah:

- Lahirnya hoax, false news, fake news atau sering disebut dengan istilah berita bohong, berita palsu, berita sesat, berita tanpa sumber (Dahlan, 2016: 52). Dalam perspektif hubungan internasional, 
Hoax telah merajalela di dalam skala dunia/global yang berakibat pada sulitnya mencari kebenaran global yang bersifat objektif dan berbasiskan data empiris. Kebenaran global telah dikonstruksi dengan menggunakan media sosial sesuai kepentingan masing - masing negara sehingga batas antara kebenaran dan kebohongan menjadi kabur dan hilang. Propaganda yang dilakukan oleh sekelompok negara untuk mencapai kepentingan nasionalnya masing-masing sering dilakukan dengan memproduksi hoax agar supaya tercipta opini publik global yang membenarkan tindakannya ke negara lain. Hoax dijadikan sebagai sarana yang ampuh untuk menciptakan "Pembenaran" atas kebohongan atau kepalsuan yang terselubung. Hoax juga telah menciptakan mispersepsi dan miskomunikasi antar negara yang berujung pada konflik antar negara maupun perang saudara antar kelompok intra negara yang hanya bersumber dari provokasi hoax yang viral di media sosial.

- Munculnya Ujaran Kebencian atau Hate Speech yang sering dilontarkan oleh berbagai tokoh, politisi, maupun para pimpinan negara yang menimbulkan ketegangan, konflik, dan kekerasan antar negara. Hate speech dikemas secara apik 
kemudian diviralkan melalui media sosial sehingga dapat diakses oleh publik global yang pada akhirnya akan menciptakan sentiment negative, provokasi SARA, maupun tindakan anarkis satu negara ke negara lain. Hate speech dilakukan sebagai sarana propaganda dalam konflik dan peperangan yang tentunya sangat membahayakan bagi perdamaian dunia, mengingat apa yang dibaca dan dipahami oleh publik melalui media sosial dianggap sebagai kebenaran sehingga diyakini dan dimasukan dalam ranah pikir setiap individu.

- Maraknya penyadapan yang dilakukan oleh berbagai pihak untuk mendapatkan informasi rahasia antar negara. Munculnya hacker, cracker maupun peretas dalam dunia maya sangat marak terjadi. Kasus "Wikileaks" dan Julian Assange menjadi contoh adanya penyadapan atau peretasan di dunia maya. Apalagi saat ini, di era media sosial, di mana setiap pemimpin negara, diplomat maupun pejabat pemerintahan menggunakan media sosial dalam melakukan aktifikasi komunikasi dan interaksi pribadi lainnya, maka sangat mudah dilakukan peretasan/penyadapan sehingga kerahasaian informasi sangat rawan bocor kepada publik. Hal ini tentu perlu diwaspadai dengan memproteksi 
sistem, software maupun aplikasi lainnya di dalam media sosial dari ancaman hacker dan cracker.

\section{Penutup}

Lanskap hubungan internasional mengalami perubahan yang signifikan dengan perkembangan teknologi informasi, komunikasi, internet, dan komputer, yang melahirkan terbentuknya jaringan media sosial, sehingga menjadikan wahana bagi aktor-aktor non-negara untuk menyuarakan aspirasi, keinginan, ide dan gagasan dalam menanggapi berbagai isu, peristiwa, maupun perundingan yang dilaksanakan oleh aktor negara dalam kancah forum-forum internasional. Media sosial dijadikan alat untuk menggalang dukungan global, mobilisasi massa global, membangun jejaring global, dan menciptakan opini publik global, yang melintasi batas antar negara, membuat aktor individu, NGO maupun organisasi lintas batas lainnya mampu berkiprah dan diperhitungkan dalam skala internasional.

Media sosial yang marak belakangan ini telah melahirkan diplomasi digital, yang diaplikasikan oleh para diplomat yang tersebar di berbagai negara, baik di kedutaan maupun di konsulat di seantero dunia, tidak terkecuali Indonesia. Praktikpraktik diplomasi telah dilakukan secara online, daring, dan wireless. Pelaksanaan tugas-tugas diplomat sudah memanfaatkan media sosial, dengan membangun akun-akun media sosial, baik akun resmi kementerian luar negeri, kedutaan, konsulat, maupun akun pribadi para diplomat masing-masing. Pemanfaatan media sosial sebagai sarana 
menunjang praktek diplomasi sangat efektif dan efisien sehingga mampu meningkatkan kualitas diplomasi dan terwujudnya kepentingan nasional.

Namun demikian, perkembangan teknologi informasi dan media sosial juga membawa implikasi negatif dalam kehidupan politik internasional, dengan munculnya hoax, fake news, false news atau sering dikenal dengan sebutan berita bohong, berita palsu dan berita sesat, di tengah dunia memasuki era post truth. Selain itu, terjadi kasus-kasus ujaran kebencian/hate speech yang dilakukan oleh para politisi dunia, pejabat dunia, maupun pemimpin dunia, yang menimbulkan potensi konflik dan kekerasan. Ditambah lagi dengan isu penyadapan/peretasan berbagai informasi global yang sangat rahasia antar negara oleh para hacker dan cracker global, khususnya di era perang informasi di dunia maya. 


\section{DAFTAR PUSTAKA}

Adesina, Olubukola S. 2016, "Foreign Policy in an Era of Digital Diplomacy", African Journal for the Psychological Study of Social Issues, Vol.19, No.3.

Bjola, Corneliu dan Holmes, Marcus. 2015, Digital Diplomacy: Theory and Practice, London and New York: Routledge.

Dahlan, Thamrin. 2016, Bukan Hoax, Jakarta : Peniti Media.

Effendy, Onong Uchjana. 2003, Imu, Teori dan Filsafat Komunikasi, Jakarta : Citra Aditya Bakti.

Feldman, Tonny. 2005, An Introduction to Digital Media, London \& New York : A Blueprint Book.

LPPM Unpar. 2017, Transformasi Strategi Diplomasi Di Era Digital : Identifikasi Postur Diplomasi Digital di Indonesia, Bandung : Desember 2017.

M. Agastya ABM. 2013, Arab Spring : Badai Revolusi Timur Tengah yang Penuh Darah, Jogjakarta : IRCiSoD.

Nasrullah, Rully. 2015, Media Sosial, Jakarta : Simbiosa Rekatamedia.

Nurudin. 2017, Perkembangan Teknologi Komunikasi, Jakarta : Rajawali Pers.

Sandre, Andreas. 2013, Twitter for Diplomats. Jenewa dan Roma : DiploFoundation and Istituto Diplomatico. 